\title{
THE MONETARY TRANSMISSION MECHANISM ${ }^{1}$
}

\author{
Peter N. Ireland ${ }^{2}$ \\ Boston College and NBER
}

October 2005

Abstract: The monetary transmission mechanism describes how policy-induced changes in the nominal money stock or the short-term nominal interest rate impact on real variables such as aggregate output and employment. Specific channels of monetary transmission operate through the effects that monetary policy has on interest rates, exchange rates, equity and real estate prices, bank lending, and firm balance sheets. Recent research on the transmission mechanism seeks to understand how these channels work in the context of dynamic, stochastic, general equilibrium models.

JEL: E52.

\footnotetext{
${ }^{1}$ Prepared for The New Palgrave Dictionary of Economics, Second Edition, edited by Lawrence Blume and Steven Durlauf, Hampshire: Palgrave Macmillan Ltd.

${ }^{2}$ Please address correspondence to: Peter N. Ireland, Boston College, Department of Economics, 140 Commonwealth Avenue, Chestnut Hill, MA 02467-3859. Tel: (617) 552-3687. Fax: (617) 552-2308. Email: irelandp@bc.edu. http://www2.bc.edu/ irelandp. Some of this work was completed while I was visiting the Research Department at the Federal Reserve Bank of Boston; I would like to thank the Bank and its staff for their hospitality and support. This material is also based on work supported by the National Science Foundation under Grant No. SES-0213461. Any opinions, findings, and conclusions or recommendations expressed herein are my own and do not reflect those of the Federal Reserve Bank of Boston, the Federal Reserve System, the National Bureau of Economic Research, or the National Science Foundation.
} 


\section{Monetary transmission mechanism}

The monetary transmission mechanism describes how policy-induced changes in the nominal money stock or the short-term nominal interest rate impact on real variables such as aggregate output and employment.

\section{Key assumptions}

Central bank liabilities include both components of the monetary base: currency and bank reserves. Hence, the central bank controls the monetary base. Indeed, monetary policy actions typically begin when the central bank changes the monetary base through an open market operation, purchasing other securities - most frequently, government bonds - to increase the monetary base and selling securities to decrease the monetary base.

If these policy-induced movements in the monetary base are to have any impact beyond their immediate effects on the central bank's balance sheet, other agents must lack the ability to offset them exactly by changing the quantity or composition of their own liabilities. Thus, any theory or model of the monetary transmission mechanism must assume that there exist no privately-issued securities that substitute perfectly for the components of the monetary base. This assumption holds if, for instance, legal restrictions prevent private agents from issuing liabilities having one or more characteristic of currency and bank reserves.

Both currency and bank reserves are nominally denominated, their quantities measured in terms of the economy's unit of account. Hence, if policy-induced movements in the nominal monetary base are to have real effects, nominal prices must not be able to respond immediately to those movements in a way that leaves the real value of the monetary base unchanged. Thus, any theory or model of the monetary transmission mechanism must also assume that some 
friction in the economy works to prevent nominal prices from adjusting immediately and proportionally to at least some changes in the monetary base.

\section{The monetary base and the short-term nominal interest rate}

If, as in the United States economy today, neither component of the monetary base pays interest or if, more generally, the components of the monetary base pay interest at a rate that is below the market rate on other highly liquid assets such as short-term government bonds, then private agents' demand for real base money $M / P$ can be described as a decreasing function of the shortterm nominal interest rate $r: M / P=\mathrm{L}(r)$. This function $\mathrm{L}$ summarizes how, as the nominal interest rate rises, other highly liquid assets become more attractive as short-term stores of value, providing stronger incentives for households and firms to economize on their holdings of currency and banks to economize on their holdings of reserves. Thus, when the price level $P$ cannot fully adjust in the short-run, the central bank's monopolistic control over the nominal quantity of base money $M$ also allows it to influence the short-term nominal interest rate $r$, with a policy-induced increase in $M$ leading to whatever decline in $r$ is necessary to make private agents willing to hold the additional volume of real base money and, conversely, a policy-induced decrease in $M$ leading to a rise in $r$. In the simplest model where changes in $M$ represent the only source of uncertainty, the deterministic relationship that links $M$ and $r$ implies that monetary policy actions can be described equivalently in terms of their effects on either the monetary base or the short-term nominal interest rate.

Poole's (1970) analysis shows, however, that when the economy is hit by random shocks of various kinds, the central bank in achieving its stabilization objectives can face a trade-off between two strategies: one of setting the nominal quantity of base money and allowing the 
market to determine the short-term nominal interest rate and the other of setting the short-term nominal interest rate and then supplying whatever quantity of nominal base money is demanded at that interest rate. More specifically, Poole's analysis reveals that central bank policy insulates output and prices from the effects of large and unpredictable disturbances to the money demand relationship by setting a target for $r$ rather than $M$. Perhaps reflecting the widespread belief that money demand shocks are large and unpredictable, most central banks around the world todayincluding the Federal Reserve in the United States - choose to conduct monetary policy with reference to a target for the short-term nominal interest rate as opposed to any measure of the money supply. Hence, in practice, monetary policy actions are almost always described in terms of their impact on a short-term nominal interest rate- such as the federal funds rate in the United States - even though, strictly speaking, those actions still begin with open market operations that change the monetary base.

\section{The channels of monetary transmission}

Mishkin (1995) usefully describes the various channels through which monetary policy actions, as summarized by changes in either the nominal money stock or the short-term nominal interest rate, impact on real variables such as aggregate output and employment.

According to the traditional Keynesian interest rate channel, a policy-induced increase in the short-term nominal interest rate leads first to an increase in longer-term nominal interest rates, as investors act to arbitrage away differences in risk-adjusted expected returns on debt instruments of various maturities as described by the expectations hypothesis of the term structure. When nominal prices are slow to adjust, these movements in nominal interest rates translate into movements in real interest rates as well. Firms, finding that their real cost of 
borrowing over all horizons has increased, cut back on their investment expenditures. Likewise, households facing higher real borrowing costs scale back on their purchases of homes, automobiles, and other durable goods. Aggregate output and employment fall. This interest rate channel lies at the heart of the traditional Keynesian textbook IS-LM model, due originally to Hicks (1937), and also appears in the more recent New Keynesian models described below.

In open economies, additional real effects of a policy-induced increase in the short-term interest rate come about through the exchange rate channel. When the domestic nominal interest rate rises above its foreign counterpart, equilibrium in the foreign exchange market requires that the domestic currency gradually depreciate at a rate that, again, serves to equate the risk-adjusted returns on various debt instruments, in this case debt instruments denominated in each of the two currencies - this is the condition of uncovered interest parity. In both traditional Keynesian models that build on Fleming (1962), Mundell (1963), and Dornbusch (1976) and in the New Keynesian models described below, this expected future depreciation requires an initial appreciation of the domestic currency that, when prices are slow to adjust, makes domesticallyproduced goods more expensive than foreign-produced goods. Net exports fall; domestic output and employment fall as well.

Additional asset price channels are highlighted by Tobin's (1969) $q$-theory of investment and Ando and Modigliani's (1963) life-cycle theory of consumption. Tobin's $q$ measures the ratio of the stock market value of a firm to the replacement cost of the physical capital that is owned by that firm. All else equal, a policy-induced increase in the short-term nominal interest rate makes debt instruments more attractive than equities in the eyes of investors; hence, following a monetary tightening, equilibrium across securities markets must be reestablished in part through a fall in equity prices. With a lower value of $q$, firms find it less desirable to issue 
new shares of stock to finance new investment projects; hence, investment, output, and employment fall. Ando and Modigliani's life-cycle theory of consumption assigns a role to wealth as well as income as key determinants of consumer spending. Hence, this theory also identifies a channel of monetary transmission: if stock prices fall after a monetary tightening, household financial wealth declines as well, leading to a fall in consumption, output, and employment.

According to Meltzer (1995), asset price movements beyond those reflected in interest rates alone also play a central role in monetarist descriptions of the transmission mechanism. Indeed, monetarist critiques of the traditional Keynesian model often start by questioning the view that the full thrust of monetary policy actions is completely summarized by movements in the short-term nominal interest rate. Monetarists argue instead that monetary policy actions impact simultaneously on prices across a wide variety of markets for financial assets and durable goods, but especially in the markets for equities and real estate, and that those asset price movements are all capable of generating important wealth effects that impact, through spending, on output and employment.

Two distinct credit channels, the bank lending channel and the balance sheet channel, also allow the effects of monetary policy actions to propagate through the real economy. Kashyap and Stein (1994) trace the origins of thought on the bank lending channel back to Roosa (1951) and also highlight Bernanke and Blinder's (1988) extension of the IS-LM model as one that accounts for this additional source of monetary nonneutrality. According to this lending view, banks play a special role in the economy not just by issuing liabilities — bank deposits_that contribute to the broad monetary aggregates, but also by holding assets — bank loans — for which few close substitutes exist. More specifically, theories and models of the bank lending 
channel emphasize that for many banks, particularly small banks, deposits represent the principal source of funds for lending and that for many firms, particularly small firms, bank loans represent the principal source of funds for investment. Hence, an open market operation that leads first to a contraction in the supply of bank reserves and then to a contraction in bank deposits requires banks that are especially dependent on deposits to cut back on their lending and firms that are especially dependent on bank loans to cut back on their investment spending. Financial market imperfections confronting individual banks and firms thereby contribute, in the aggregate, to the decline in output and employment that follows a monetary tightening.

Bernanke and Gertler (1995) describe a broader credit channel, the balance sheet channel, where financial market imperfections also play a key role. Bernanke and Gertler emphasize that in the presence of financial market imperfections, a firm's cost of credit, whether from banks or any other external source, rises when the strength of its balance sheet deteriorates. A direct effect of monetary policy on the firm's balance sheet comes about when an increase in interest rates works to increase the payments that the firm must make to service its floating rate debt. An indirect effect arises, too, when the same increase in interest rates works to reduce the capitalized value of the firm's long-lived assets. Hence, a policy-induced increase in the short-term interest rate not only acts immediately to depress spending through the traditional interest rate channel, it also acts, possibly with a lag, to raise each firm's cost of capital through the balance sheet channel, deepening and extending the initial decline in output and employment.

\section{Recent developments}

Recent theoretical work on the monetary transmission mechanism seeks to understand how the traditional Keynesian interest rate channel operates within the context of dynamic, stochastic, 
general equilibrium models. This recent work builds on early attempts by Fischer (1977) and Phelps and Taylor (1977) to combine the key assumption of nominal price or wage rigidity with the assumption that all agents have rational expectations so as to overturn the policy ineffectiveness result that McCallum (1979) associates with Lucas (1972) and Sargent and Wallace (1975). This recent work builds on those earlier studies by deriving the key behavioral equations of the New Keynesian model from more basic descriptions of the objectives and constraints faced by optimizing households and firms.

More specifically, the basic New Keynesian model consists of three equations involving three variables: output $y_{t}$, inflation $\pi_{t}$, and the short-term nominal interest rate $r_{t}$. The first equation, which Kerr and King (1996) and McCallum and Nelson (1999) dub the expectational IS curve, links output today to its expected future value and to the ex-ante real interest rate, computed in the usual way by subtracting the expected rate of inflation from the nominal interest rate:

$$
y_{t}=E_{t} y_{t+1}-\sigma\left(r_{t}-E_{t} \pi_{t+1}\right)
$$

where $\sigma$, like all of the other parameters to be introduced below, is strictly positive. This equation corresponds to a log-linearized version of the Euler equation linking an optimizing household's intertemporal marginal rate of substitution to the inflation-adjusted return on bonds, that is, to the real interest rate. The second equation, the New Keynesian Phillips curve, takes the form

$$
\pi_{t}=\beta E_{t} \pi_{t+1}+\gamma y_{t}
$$

and corresponds to a log-linearized version of the first-order condition describing the optimal behavior of monopolistically competitive firms that either face explicit costs of nominal price adjustment, as suggested by Rotemberg (1982), or set their nominal prices in randomly staggered 
fashion, as suggested by Calvo (1983). The third and final equation is an interest rate rule for monetary policy of the type proposed by Taylor (1993),

$$
r_{t}=\alpha \pi_{t}+\psi y_{t}
$$

according to which the central bank systematically adjusts the short-term nominal interest in response to movements in inflation and output. This description of monetary policy in terms of interest rates reflects the observation, noted above, that most central banks today conduct monetary policy using targets for the interest rate as opposed to any of the monetary aggregates; a money demand equation could be appended to this three-equation model, but that additional equation would serve only to determine the amount of money that the central bank and the banking system would have to supply to clear markets, given the setting for central bank's interest rate target—see Ireland (2004) for a detailed discussion of this last point.

In this benchmark New Keynesian model, monetary policy operates through the traditional Keynesian interest rate channel. A monetary tightening in the form of a shock to the Taylor rule that increases the short-term nominal interest rate translates into an increase in the real interest rate as well when nominal prices move sluggishly due to costly or staggered price setting. This rise in the real interest rate then causes households to cut back on their spending as summarized by the IS curve. Finally, through the Phillips curve, the decline in output puts downward pressure on inflation, which adjusts only gradually after the shock.

Importantly, however, the expectational terms that enter into the IS and Phillips curves displayed above imply that policy actions will differ in their quantitative effects depending on whether those actions are anticipated or unanticipated; hence, this New Keynesian model follows the earlier rational expectations models of Lucas and Sargent and Wallace by stressing the role of expectations in the monetary transmission mechanism. And, as emphasized by Kimball 
(1995), by deriving these expectational forms for the IS and Phillips curves from completely spelled-out descriptions of the optimizing behavior of households and firms, the New Keynesian model takes advantage of the powerful microeconomic foundations introduced into macroeconomics through Kydland and Prescott's (1982) real business cycle model while also drawing on insights from earlier work in New Keynesian economics as exemplified, for instance, by the articles collected in Mankiw and Romer's (1991) two-volume set.

Clarida, Gali, and Gertler (1999) and Woodford (2003) trace out the New Keynesian model's policy implications in much greater detail. Obstfeld and Rogoff (1995) develop an open-economy extension in which the exchange rate channel operates together with the interest rate channel of monetary transmission. And, similarly, Bernanke, Gertler, and Gilchrist (1999) extend the New Keynesian model to account for the balance sheet channel of monetary transmission.

Other recent work on the monetary transmission mechanism focuses on the problem of the zero lower bound on nominal interest rates - a problem that appears most starkly in the basic New Keynesian model sketched out above, in which monetary policy affects the economy exclusively through the Keynesian interest rate channel. Private agents always have the option of using currency as a store of value; hence, equilibrium in the bond market requires a nonnegative nominal interest rate. In a low inflation environment where nominal interest rates are also low on average, the central bank may bump up against this zero lower bound and find itself unable to provide further monetary stimulus after the economy is hit by a series of adverse shocks. Interest in the zero lower bound grew during the late 1990s and early 2000s when, in fact, nominal interest rates approached zero in Japan, the United States, and a number of other 
countries. Krugman's (1998) paper, one of the first to call attention to this problem, draws parallels between the zero lower bound and the traditional Keynesian liquidity trap.

Finally, on the empirical front, quite a bit of recent work looks for evidence of quantitatively important credit channels of monetary transmission. Kashyap and Stein (1994) and Bernanke, Gertler, and Gilchrist (1996) survey this branch of the literature. Also, the striking rise in equity and real estate prices over the past decade in the United States, the United Kingdom, and elsewhere has sparked renewed interest in quantifying the importance of the asset price channels described above. Noteworthy contributions along these lines include Lettau and Ludvigson (2004) and Case, Quigley, and Shiller (2005).

\section{Bibliography}

Ando, A. and Modigliani, F. 1963. The "Life Cycle" Hypothesis of Saving: Aggregate Implications and Tests. American Economic Review 53, 55-84.

Bernanke, B.S. and Blinder, A.S. 1988. Credit, Money, and Aggregate Demand. American Economic Review 78, 435-439.

Bernanke, B.S. and Gertler, M. 1995. Inside the Black Box: The Credit Channel of Monetary Policy Transmission. Journal of Economic Perspectives 9, 27-48.

Bernanke, B.S., Gertler, M. and Gilchrist, S. 1996. The Financial Accelerator and the Flight to Quality. Review of Economics and Statistics 78, 1-15.

Bernanke, B.S., Gertler, M. and Gilchrist, S. 1999. The Financial Accelerator in a Quantitative Business Cycle Framework. In J.B. Taylor and M. Woodford, Eds. Handbook of Macroeconomics. Amsterdam: Elsevier. 
Calvo, G.A. 1983. Staggered Prices in a Utility-Maximizing Framework. Journal of Monetary Economics 12, 383-398.

Case, K.E., Quigley, J.M., and Shiller, R.J. 2005. Comparing Wealth Effects: The Stock Market versus the Housing Market. Advances in Macroeconomics 5, Article 1.

Clarida, R., Gali, J. and Gertler, M. 1999. The Science of Monetary Policy: A New Keynesian Perspective. Journal of Economic Literature 37, 1661-1707.

Dornbusch, R. 1976. Expectations and Exchange Rate Dynamics. Journal of Political Economy $84,1161-1176$.

Fischer, S. 1977. Long-Term Contracts, Rational Expectations, and the Optimal Money Supply Rule. Journal of Political Economy 85, 191-205.

Fleming, J.M. 1962. Domestic Financial Polices Under Fixed and Under Floating Exchange Rates. International Monetary Fund Staff Papers 9, 369-379.

Hicks, J.R. 1937. Mr. Keynes and the "Classics"; A Suggested Interpretation. Econometrica 5, $147-159$.

Ireland, P.N. 2004. Money's Role in the Monetary Business Cycle. Journal of Money, Credit, and Banking 36, 969-983.

Kashyap, A.K. and Stein, J.C. 1994. Monetary Policy and Bank Lending. In N.G. Mankiw, Ed. Monetary Policy. Chicago: University of Chicago Press.

Kerr, W. and King, R.G. 1996. Limits on Interest Rate Rules in the IS Model. Federal Reserve Bank of Richmond Economic Quarterly 82, 47-75.

Kimball, M.S. 1995. The Quantitative Analytics of the Basic Neomonetarist Model. Journal of Money, Credit, and Banking 27, 1241-1277. 
Krugman, P.R. 1998. It's Baaack: Japan's Slump and the Return of the Liquidity Trap. Brookings Papers on Economic Activity 2, 137-187.

Kydland, F.E. and Prescott, E.C. 1982. Time to Build and Aggregate Fluctations. Econometrica $50,1345-1370$.

Lettau, M. and Ludvigson, S.C. 2004. Understanding Trend and Cycle in Asset Values: Reevaluating the Wealth Effect on Consumption. American Economic Review 94, 276299.

Lucas Jr., R.E. 1972. Expectations and the Neutrality of Money. Journal of Economic Theory 4, 103-124.

Mankiw, N.G. and Romer, D. 1991. New Keynesian Economics. Volume 1: Imperfect Competition and Sticky Prices. Volume 2: Coordination Failures and Real Rigidities. Cambridge: MIT Press.

McCallum, B.T. 1979. The Current State of the Policy-Ineffectiveness Debate. American Economic Review 69, 240-245.

McCallum, B.T. and Nelson, E. 1999. An Optimizing IS-LM Specification for Monetary Policy and Business Cycle Analysis. Journal of Money, Credit, and Banking 31, 296-316.

Meltzer, A.H. 1995. Monetary, Credit and (Other) Transmission Processes: A Monetarist Perspective. Journal of Economic Perspectives 9, 49-72.

Mishkin, F.S. 1995. Symposium on the Monetary Transmission Mechanism. Journal of Economic Perspectives 9, 3-10.

Mundell, R.A. 1963. Capital Mobility and Stabilization Policy under Fixed and Flexible Exchange Rates. Canadian Journal of Economics and Political Science 29, 475-485. 
Obstfeld, M. and Rogoff, K. 1995. Exchange Rate Dynamics Redux. Journal of Political Economy 103, 624-660.

Phelps, E.S. and Taylor, J.B. 1977. Stabilizing Powers of Monetary Policy under Rational Expectations. Journal of Political Economy 85, 163-190.

Poole, W. 1970. Optimal Choice of Monetary Policy Instruments in a Simple Stochastic Macro Model. Quarterly Journal of Economics 84, 197-216.

Roosa, R.V. 1951. Interest Rates and the Central Bank. In Money, Trade, and Economic Growth: Essays in Honor of John Henry Williams. New York: Macmillan.

Rotemberg, J.J. 1982. Sticky Prices in the United States. Journal of Political Economy 90, 11871211.

Sargent, T.J. and Wallace, N. "Rational" Expectations, the Optimal Monetary Instrument, and the Optimal Money Supply Rule. Journal of Political Economy 83, 241-254.

Taylor, J.B. 1993. Discretion versus Policy Rules in Practice. Carnegie-Rochester Conference Series on Public Policy 39, 195-214.

Tobin, J. 1969. A General Equilibrium Approach to Monetary Theory. Journal of Money, Credit, and Banking 1, 15-29.

Woodford, M. 2003. Interest and Prices: Foundations of a Theory of Monetary Policy. Princeton: Princeton University Press. 